\title{
Ocena korelacji odporności na utlenianie paliw do silników wysokoprężnych oraz skłonności do blokowania filtrów paliw
}

\begin{abstract}
Stabilność oksydacyjna i tendencja do blokowania filtrów paliwowych są podstawowymi oznaczanymi obecnie właściwościami eksploatacyjnymi paliw do silników z zapłonem samoczynnym. W artykule przedstawiono wyniki badań korelacji między stabilnością oksydacyjną mierzoną według PN-EN 15751, a tendencją do blokowania filtrów paliw według ASTM D 2068.
\end{abstract}

Słowa kluczowe: stabilność oksydacyjna, blokada filtra paliw, FBT, Rancimat.

\section{Correlation oxidation stability of diesel fuel and filter blocking tendency}

Oxidation stability and filter blocking tendency are very important in the quality control of diesel fuel. The article presents results of research correlation between these parameters.

Key words: oxidation stability, filter blocking tendency, FBT, Rancimat.

Kraje Unii Europejskiej, w tym Polska, kładą duży nacisk na działania proekologiczne, między innymi na modernizację silników wysokoprężnych umożliwiającą uzyskanie większej mocy silnika przy mniejszym zużyciu paliwa.

W związku z bardzo wysokimi parametrami nowych układów paliwowych, w tym układów common rail, w których wymagana jest największa precyzja obróbki mechanicznej, wynikająca z coraz to mniejszych tolerancji i dokładniejszych pasowań, zanieczyszczenia występujące w paliwie mogą przyczynić się do szybkiego zużycia tych układów, a nawet do ich poważnego uszkodzenia. Wynikają stąd duże wymagania dotyczące jakości paliwa i dokładności jego oczyszczania, a dopuszczalne wielkości zanieczyszczeń są coraz mniejsze [1]. Paliwo niespełniające wymagań w tym zakresie może w krótkim czasie spowodować uszkodzenie bardzo kosztownej aparatury wtryskowej.

Głównym źródłem zanieczyszczeń paliw są [5]:

- zanieczyszczenia produkcyjne z instalacji rafineryjnych,

- zanieczyszczenia powstałe w wyniku transportu w cysternach i przechowywania w zbiornikach stacji paliw,

- zanieczyszczenia dostające się z zewnątrz w trakcie na- pełniania układów lub w przypadku ich nieszczelności (np. woda),

- zanieczyszczenia powstałe w wyniku wzajemnej współpracy elementów układu paliwowego: tarcia, ciśnienia, temperatury, np. w trakcie przepompowywania paliwa,

- zanieczyszczenia powstałe w wyniku oddziaływania z uszczelnieniami oraz przewodami elastomerowymi,

- zanieczyszczenia powstałe w wyniku procesów utleniania w trakcie przechowywania,

- zanieczyszczenia związane z korozją i destrukcją powierzchni układów,

- zanieczyszczenia wytrącone w wyniku interakcji różnych składników paliwa,

- brak kompatybilności paliwa z materiałami konstrukcyjnymi układu paliwowego.

Jedną z przyczyn powstawania zanieczyszczeń w postaci osadów i szlamów są procesy utleniania zachodzące w paliwie. Po wprowadzeniu do użytkowania alternatywnych paliw zawierających komponenty pochodzące z odnawialnych źródeł energii, zwłaszcza tych o zwięksszonej zawartości FAME, procesy te stały się jeszcze intensywniejsze. 
Zmiany formulacji paliwowych wpływają w sposób niekorzystny na właściwości fizyczne i chemiczne paliw. Kilkuprocentowa zawartość FAME w oleju napędowym może powodować problemy z dotrzymaniem wielu parametrów jakościowych, zawartych w wymaganiach w normie PN-EN 590 Paliwa do pojazdów samochodowych. Oleje napędowe. Wymagania i metody badań.

Ze względu na chemizm procesów utleniania FAME, całkowicie odmienny od utleniania frakcji węglowodorowych, już kilkuprocentowa jego zawartość w paliwie może powodować problemy z dotrzymaniem minimalnych, przyjętych w wyżej wymienionej normie, parametrów stabilności oksydacyjnej. Stosowane dodatki przeciwutleniające nie zatrzymują przebiegających w paliwie reakcji utleniania, a jedynie je opóźniają [4]. Produkty utleniania FAME zawarte w paliwie mogą również powodować problemy z filtracją paliwa, aż do całkowitej blokady filtrów paliwowych w trakcie eksploatacji pojazdów mechanicznych.

Problemem nie są, jak początkowo sądzono, parafiny wytrącające się w okresach niskiej temperatury, lecz różnego typu żele utrudniające filtrację. Proces ten nie jest odwracalny, inaczej niż w przypadku parafin, które ulegają rozpuszczeniu w wyższej temperaturze czy po zastosowaniu odpowiednich dodatków. Filtr zablokowany żelami musi zostać wymieniony. Udowodniono jednoznacznie, iż żele te pochodzą ze stosowanych w paliwach biokomponentów (FAME) oraz dodatków stabilizujących procesy utleniania [2].

Można stwierdzić, że zmiany konstrukcji silników oraz zmiany formulacji paliwowych wpłynęły na większe zainteresowanie problematyką stabilności oksydacyjnej oraz filtracji paliwa.

Parametr „stabilność oksydacyjna paliwa” jest bardzo istotny z punktu widzenia użytkownika pojazdów mechanicznych. Stabilność oksydacyjna paliwa ma wpływ zarówno na eksploatację pojazdu, jak również na żywotność wielu jego podzespołów. Paliwo niespełniające wymagań w zakresie stabilności oksydacyjnej w trakcie przechowywania, zwłaszcza w okresie letnim, ulega szybkiemu utlenianiu. Proces ten następuje samorzutnie i tworzą się: alkohole, ketony, etery, kwasy organiczne, aldehydy i oligomery. Z paliwa wytrącają się osady i żywice (fotografia 1).

Powstałe produkty utleniania mogą uszkadzać pompy paliwowe, blokować filtry i przewody paliwowe. Osadzając się na końcówkach wtryskiwaczy, zaburzają one proces wtrysku paliwa. Kwaśne produkty utleniania mogą przyczyniać się do degradowania elementów silnika, powodując zwiększoną korozję oraz szybsze niszczenie różnego rodzaju uszczelnień.

Stabilność oksydacyjna paliwa do silników z zapłonem samoczynnym, w skład którego wchodzi FAME, zależy od wielu czynników, a wśród nich od [3]:
- jakości produktów (głównie jakości FAME) użytych do komponowania paliwa,

- użytych dodatków antyutleniających,

- użytych innych dodatków, np. poprawiających liczbę cetanową, biocydów itd.,

- sposobu przechowywania (temperatura, kontakt z powietrzem atmosferycznym, kontakt z wodą, światło słoneczne),

- kontaktu z metalami nieżelaznymi (miedzią, niklem), stopami (brązem, mosiądzem),

- kontaktu z uszczelnieniami elastomerowymi.
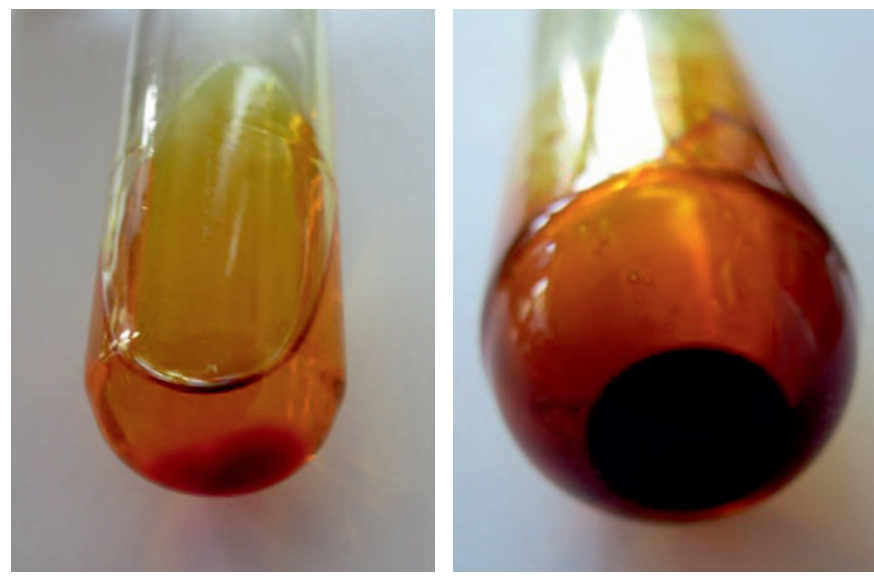

Fot. 1. Wygląd utlenionych próbek oleju napędowego (zawartość FAME: 6,7\%). Na dnie jednej z probówek widoczny żelowy osad, a na dnie drugiej osad trwale przylegający. Test wykonano zgodnie z normą PN-EN 15751 (fot. INiG - PIB)

Powstałe w procesie utleniania osady i żele, tworząc złogi, mogą wpływać na przepływ paliwa w układzie paliwowym pojazdów mechanicznych. Mogą pojawić się problemy z przepływem paliwa przez filtry paliwowe, stosowane w układach zasilania silników wysokoprężnych.

Materiały filtracyjne wykorzystywane w filtrach paliwa są to wielowarstwowe przegrody filtracyjne, odporne na działanie paliw. Charakteryzują się one zdolnością do kondensacji wody na włókninie, odpornością na działanie dodatków chemicznych zawartych w paliwie, dużą chłonnością cząstek oraz dobrą skutecznością oddzielania wody z paliwa.

Głównym zadaniem filtrów paliwowych jest zabezpieczenie gładkich powierzchni elementów pomp i wtryskiwaczy przed uszkodzeniem.

Wcześniej stosowane filtry miały za zadanie jedynie eliminować z paliw cząstki stałe (brud) i wodę. Obecnie muszą uporać się również z problemem takich zanieczyszczeń jak produkty degradacji paliwa, w tym zwiększonego utleniania biopaliw (fotografie 2, 3, 4). Obecnie te problemy są w 95\% przyczyną uszkodzenia filtrów bądź ich przedwczesnej blokady. Czynniki takie jak zanieczyszczenia mechaniczne czy 
wydzielana pod wpływem niskiej temperatury parafina zeszły na dalszy plan [2].

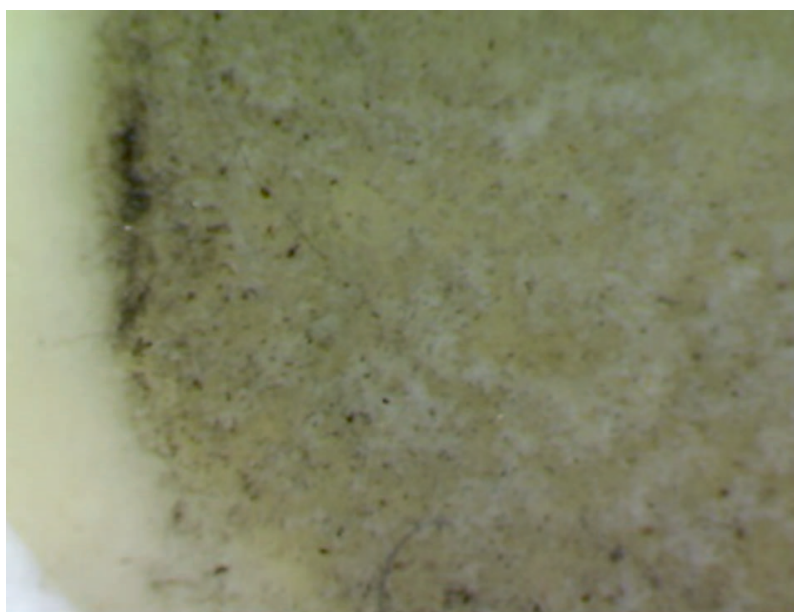

Fot. 2. Wygląd powierzchni sączka po teście ASTM D 2068 dla oleju napędowego o zawartości FAME poniżej 2\%. $\mathrm{Na}$ sączku widoczne zanieczyszczenia mechaniczne (fot. INiG - PIB)

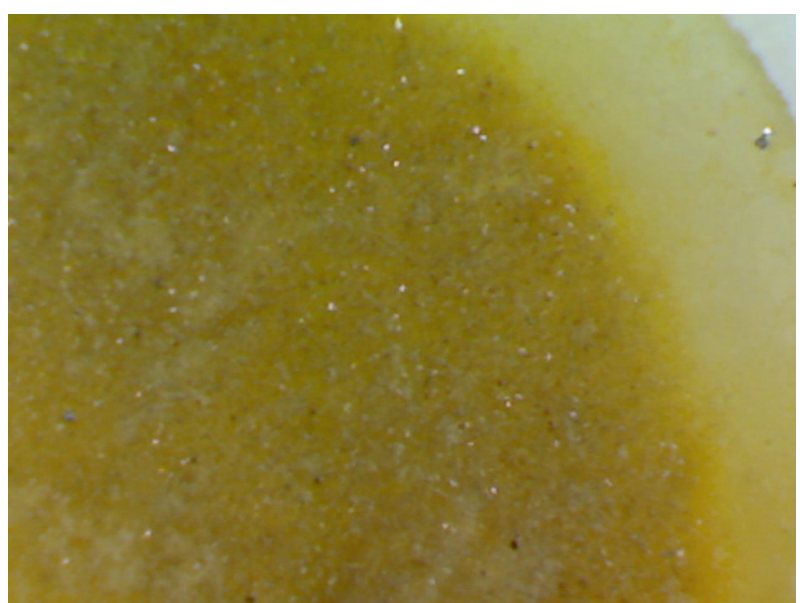

Fot. 3. Wygląd powierzchni sączka po teście ASTM D 2068 dla oleju napędowego o zawartości FAME 7,2\% (fot. INiG - PIB)

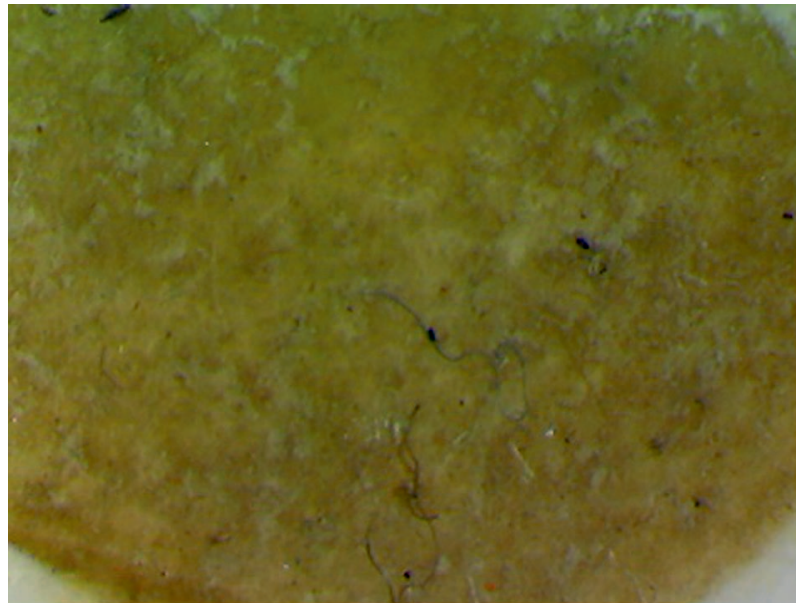

Fot. 4. Wygląd powierzchni sączka po teście ASTM D 2068 dla oleju napędowego o zawartości FAME 100\% (fot. INiG - PIB)
W trakcie eksploatacji zanieczyszczenia, osadzając się na filtrach, stopniowo zmniejszają przepływ paliwa, aż do jego całkowitego zablokowania.

W odpowiedzi na problemy użytkowników pojazdów z blokującymi się filtrami paliw, zwłaszcza pojazdów, do których stosowane są paliwa zawierające w swym składzie FAME, wprowadzono nowy test określający tendencję paliw do blokowania filtrów paliwowych (ASTM D 2068). Miarą tej tendencji jest bezwymiarowy wskaźnik FBT, obliczany zgodnie z przytoczonymi w normie wzorami, zależnymi od ilości przefiltrowanego paliwa oraz od ciśnienia panującego w układzie filtracyjnym. Wskaźnik FBT mierzy się w celu ustalenia, jak duży wpływ na czas użytkowania filtrów paliw w pojazdach mechanicznych będą miały zawarte w paliwie zanieczyszczenia stałe i żelowe.

Niektóre kraje Unii Europejskiej wprowadziły do wymagań dobrowolny test tendencji do blokowania filtrów paliw według ASTM D 2068, ustalając limit dla oleju napędowego $\mathrm{FBT}=2,52[6]$.

$\mathrm{Z}$ uwagi na fakt, że w trakcie procesów utleniania powstają różnego rodzaju osady typu żele i żywice, postanowiono przeprowadzić badania pozwalające stwierdzić, czy istnieje zależność między stabilnością oksydacyjną biopaliw oraz paliw zawierających różną procentową zawartość FAME a parametrem określającym tendencję do blokowania filtrów paliwowych. W ramach realizowanego projektu wykonano badania mające na celu określenie zależności wskaźnika FBT od stabilności oksydacyjnej. Badaniami objęto paliwa handlowe o różnych udziałach objętościowych FAME, wynoszących od 0,02\% do 7,2\% $(V / V)$, próbki FAME od różnych producentów oraz próbki paliw zestawianych $\mathrm{w} I \mathrm{NiG}$ - PIB z paliwa bazowego i dwóch próbek FAME różniących się wskaźnikiem FBT. Ocenę stabilności oksydacyjnej wykonano z zastosowaniem aparatów Rancimat (PN-EN 15751) oraz zestawu do utleniania zgodnego z normą PN-ISO 12205. Tendencję do blokowania filtrów paliw określono przy użyciu aparatu Normalab NBF 240, zgodnie z normą ASTM D 2068.

Na rysunkach 1, 2 i 3 przedstawiono wyniki badania stabilności oksydacyjnej wyznaczonej zgodnie z normą PN-EN 15751 oraz tendencji do blokowania filtrów paliwowych FBT według ASTM D 2068 próbek olejów handlowych o zawartości FAME od $0 \%$ do 7,3\% oraz czystego FAME. Próbki uszeregowano według rosnącej stabilności oksydacyjnej.

Na rysunkach 4, 5 i 6 przedstawiono wyniki badania stabilności oksydacyjnej wyznaczonej zgodnie z normą PN-EN 12205 oraz tendencji do blokowania filtrów paliwowych FBT według ASTM D 2068 próbek olejów handlowych o zawartości FAME od $0 \%$ do 7,3\%. Próbki uszeregowano według rosnącej stabilności oksydacyjnej. 


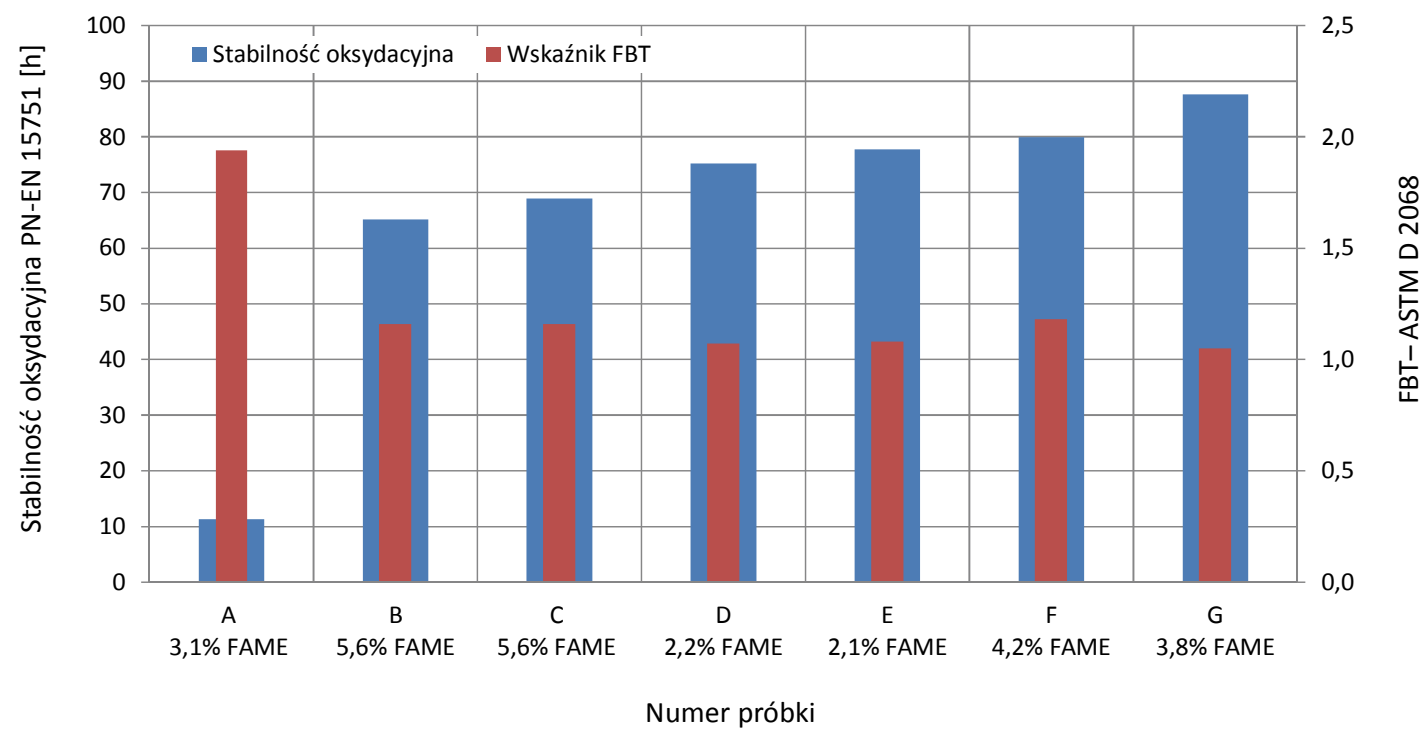

Rys. 1. Oleje handlowe o zawartości FAME od 2\% do 6\%

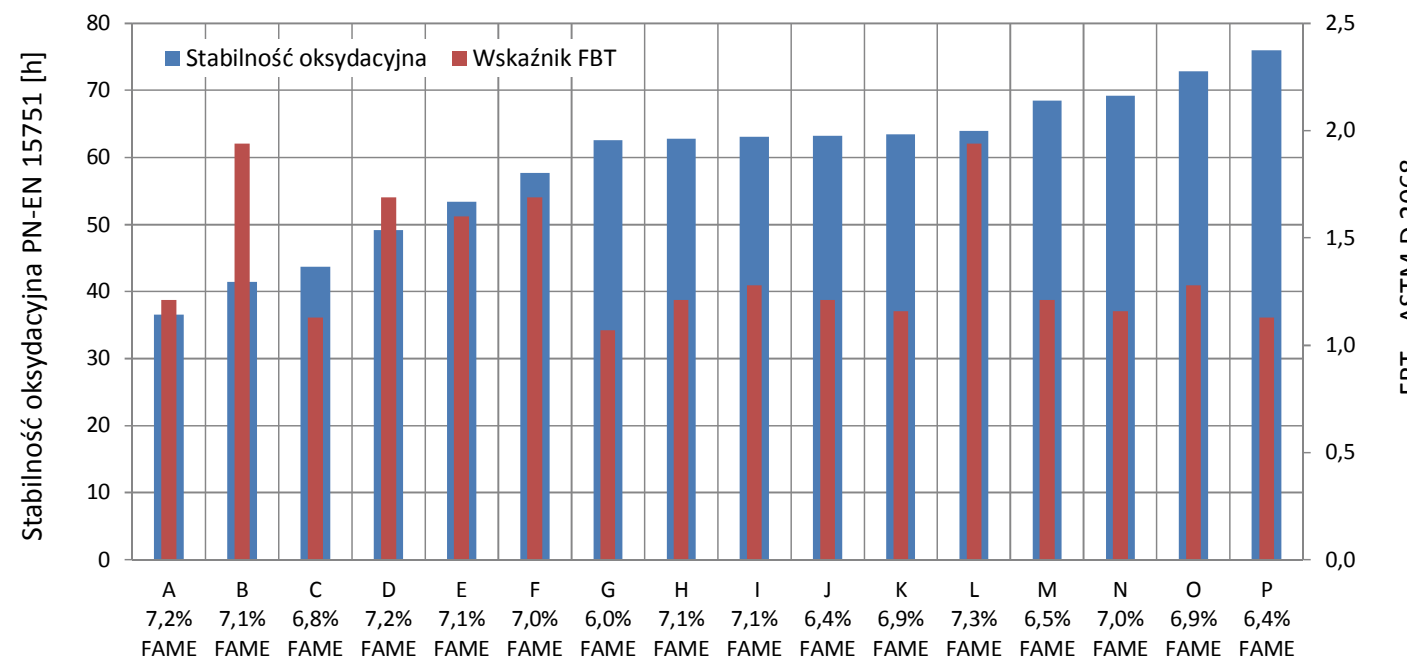

Numer próbki

Rys. 2. Oleje handlowe o zawartości FAME od 6,0\% do 7,3\%

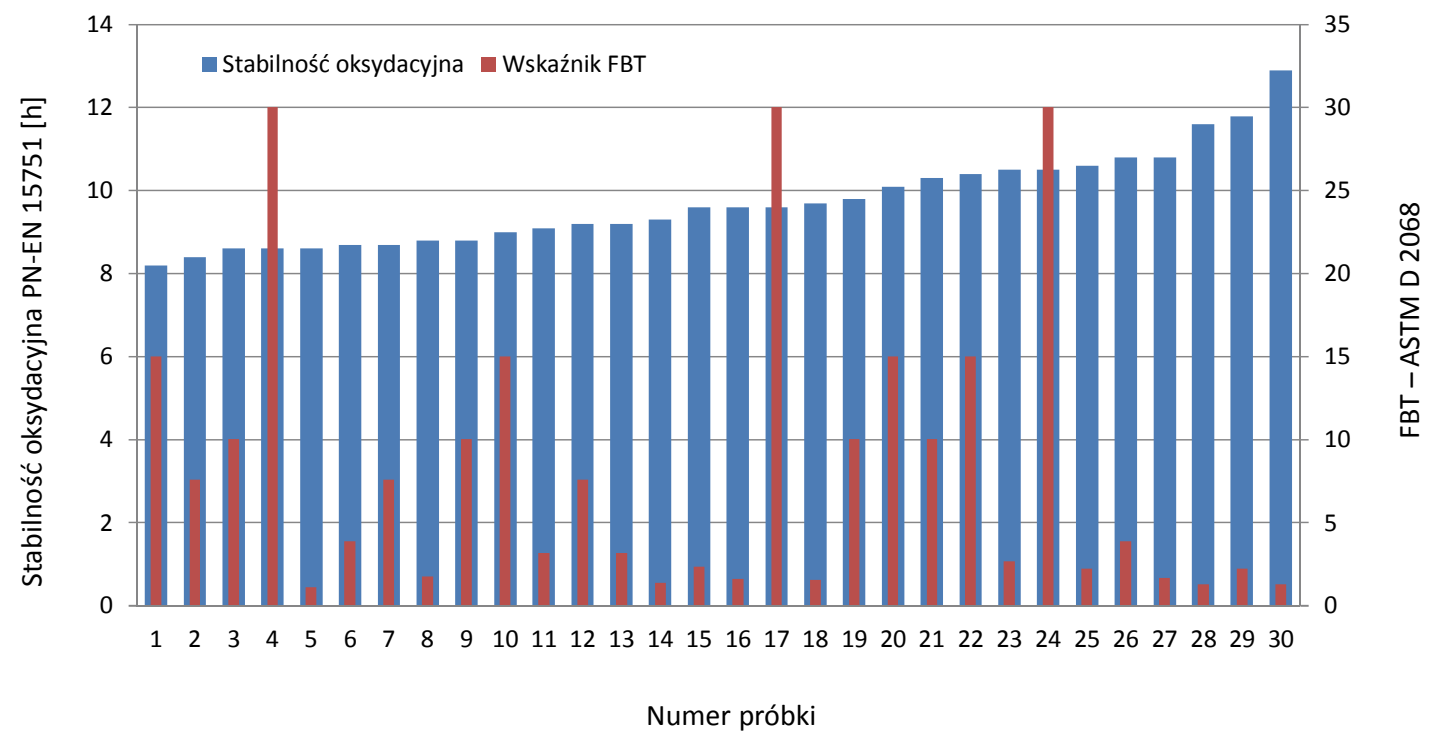

Rys. 3. Próbki FAME (100\% FAME) 


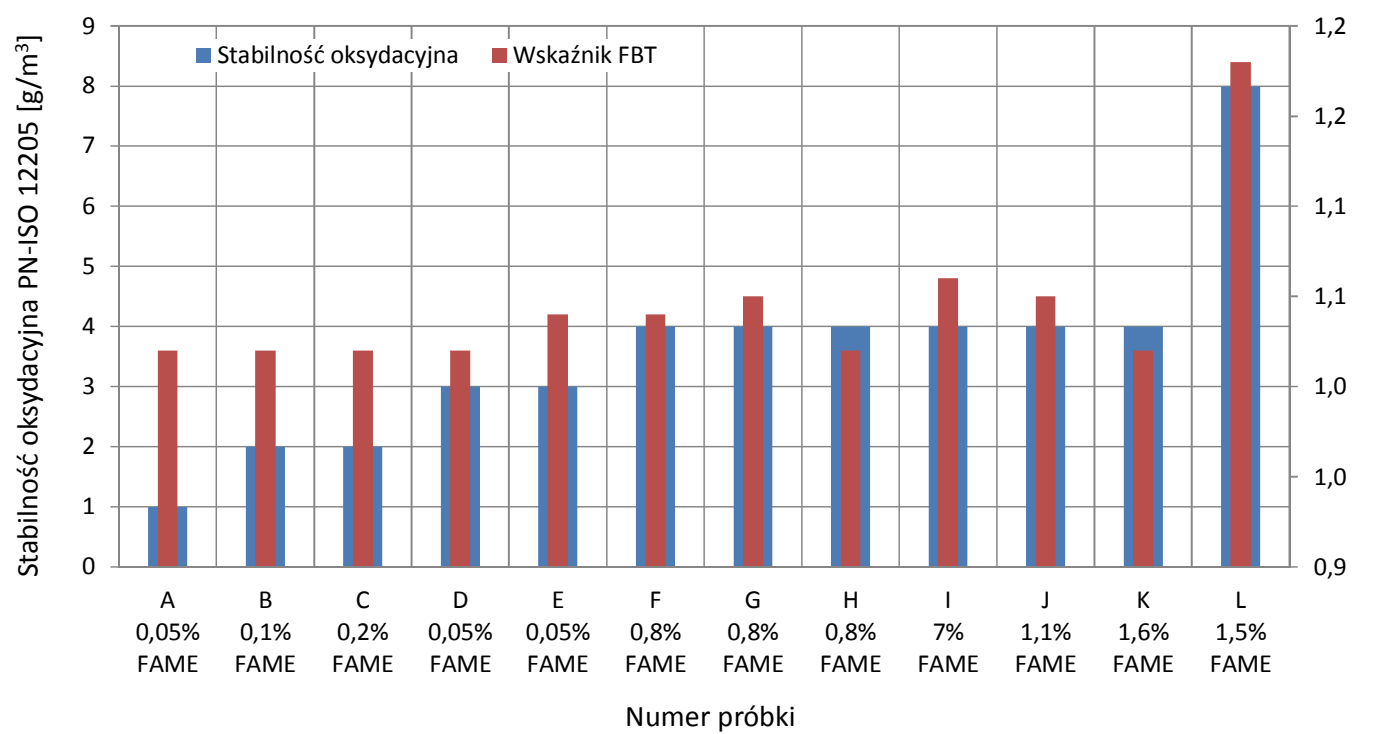

Rys. 4. Oleje handlowe o zawartości FAME od $0 \%$ do 2\%

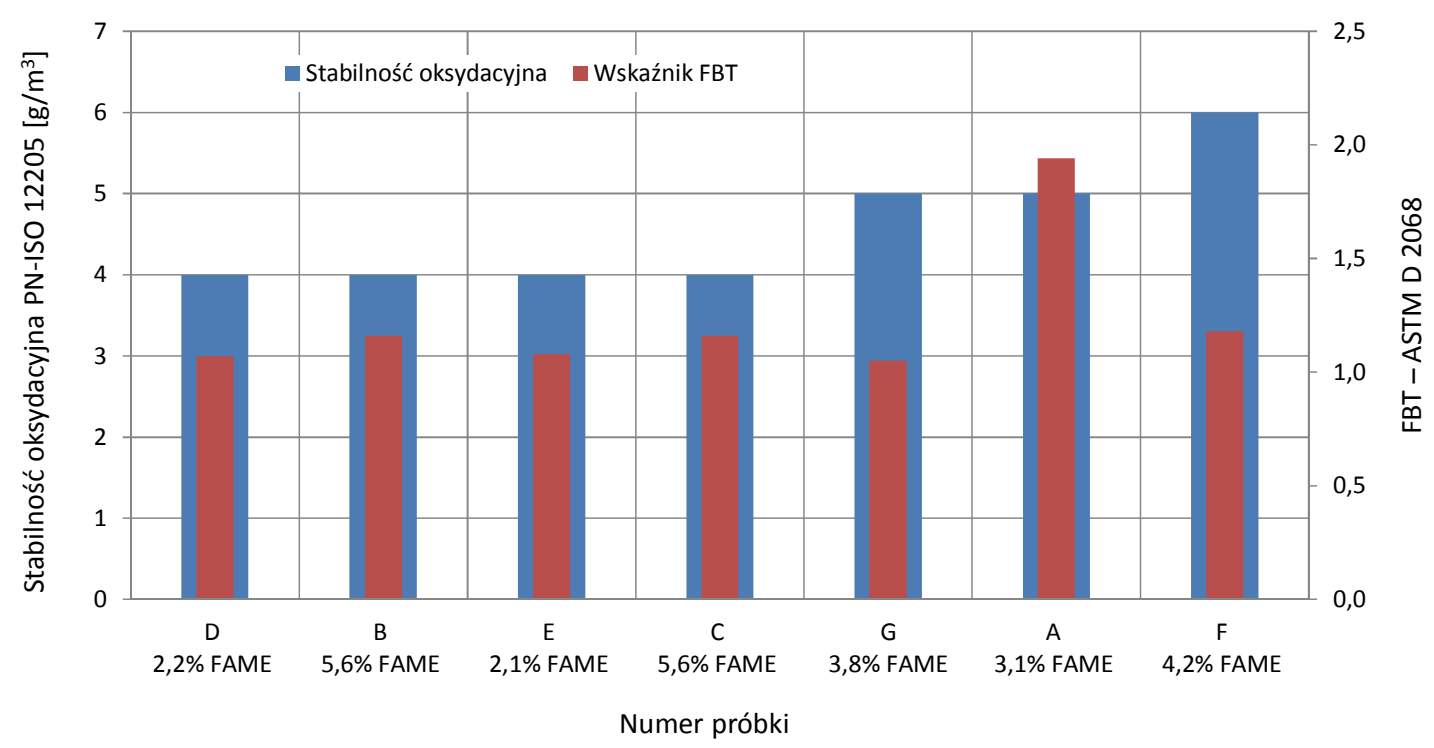

Rys. 5. Oleje handlowe o zawartości FAME od 2\% do 6\%

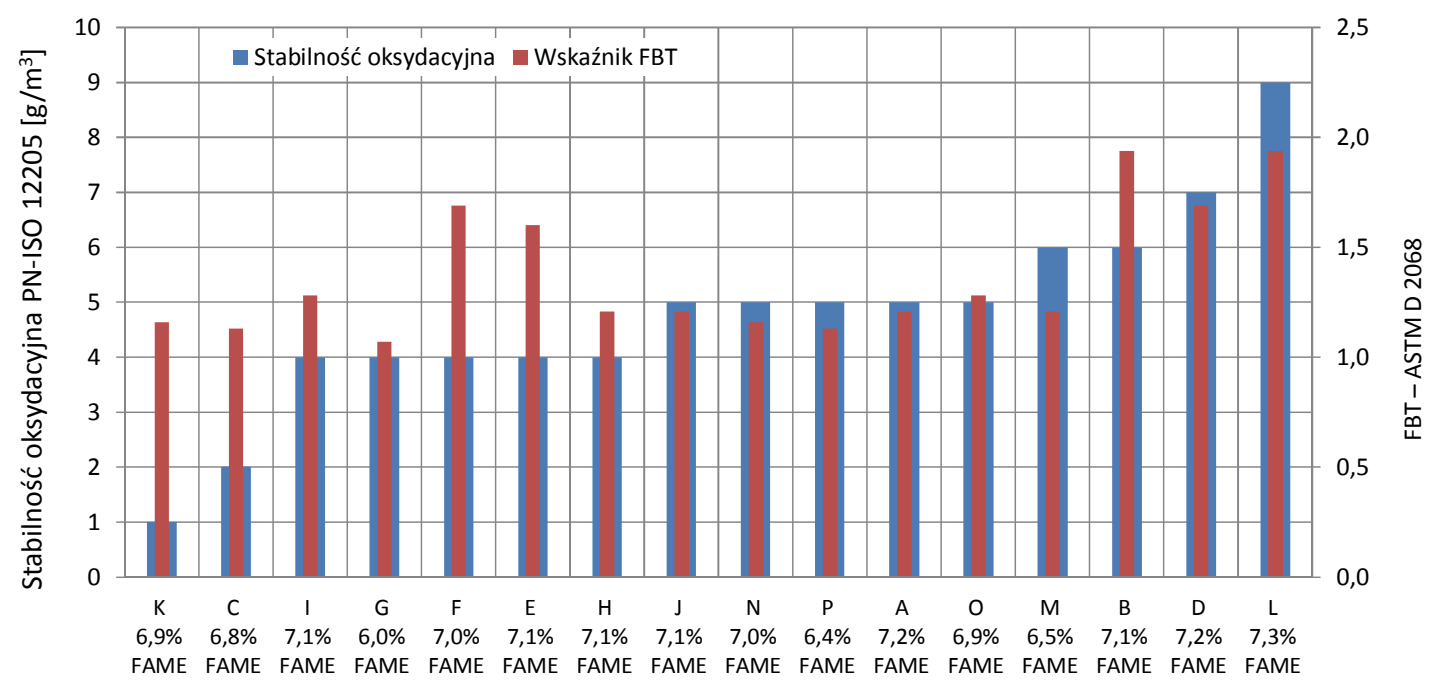

Numer próbki

Rys. 6. Oleje handlowe o zawartości FAME od 6,0\% do 7,3\% 
Na rysunku 7 przedstawiono, jak kształtuje się wskaźnik FBT i stabilność oksydacyjna wyznaczona zgodnie z PN-EN 15751 próbek zestawionych w INiG - PIB, a na rysunku 8 przedstawiono te same wielkości po miesiącu przechowywania próbek w warunkach pokojowych.

Na podstawie wykonanych badań stwierdzono, że w warunkach ich przeprowadzenia nie można jednoznacznie wyznaczyć korelacji między stabilnością oksydacyjną, określoną jedną z wyżej podanych metod badawczych, a wskaźnikiem FBT. Stwierdzono, że wskaźnik FBT dla paliw handlowych o zawartości FAME do 7\% nie przekracza wartości FBT $=2$ zarówno $\mathrm{w}$ przypadku paliw o stabilności oksydacyjnej wyznaczonej zgodnie z metodą PN-EN 15751 bliskiej wartości granicznej 20 h, jak i tych o stabilności oksydacyjnej bliskiej $100 \mathrm{~h}$.
Na podstawie badań przeprowadzonych na tych próbkach nie stwierdzono zależności wielkości wskaźnika FBT od stabilności oksydacyjnej.

Można zauważyć wzrost wartości wskaźnika FBT w zależności od procentowego udziału FAME w paliwie. W przypadku paliw o zawartości FAME od 0,0\% do $1 \%(V / V)$ uśredniony wskaźnik FBT równy jest 1,04 . Uśredniony wskaźnik FBT próbek paliwa o udziale FAME od 1\% do $6 \%(V / V)$ równy jest 1,23 , natomiast gdy zawartość FAME mieści się w przedziale od $6 \%$ do $7 \%(V / V)$, wynosi on 1,87 . W przypadku wyższych udziałów procentowych FAME w paliwie wskaźnik określający tendencję do blokowania filtrów paliwowych FBT jest wyższy.

Wskaźnik FBT próbek FAME, mimo iż spełniały one wymagania normy przedmiotowej PN-EN 14214 (stabilność

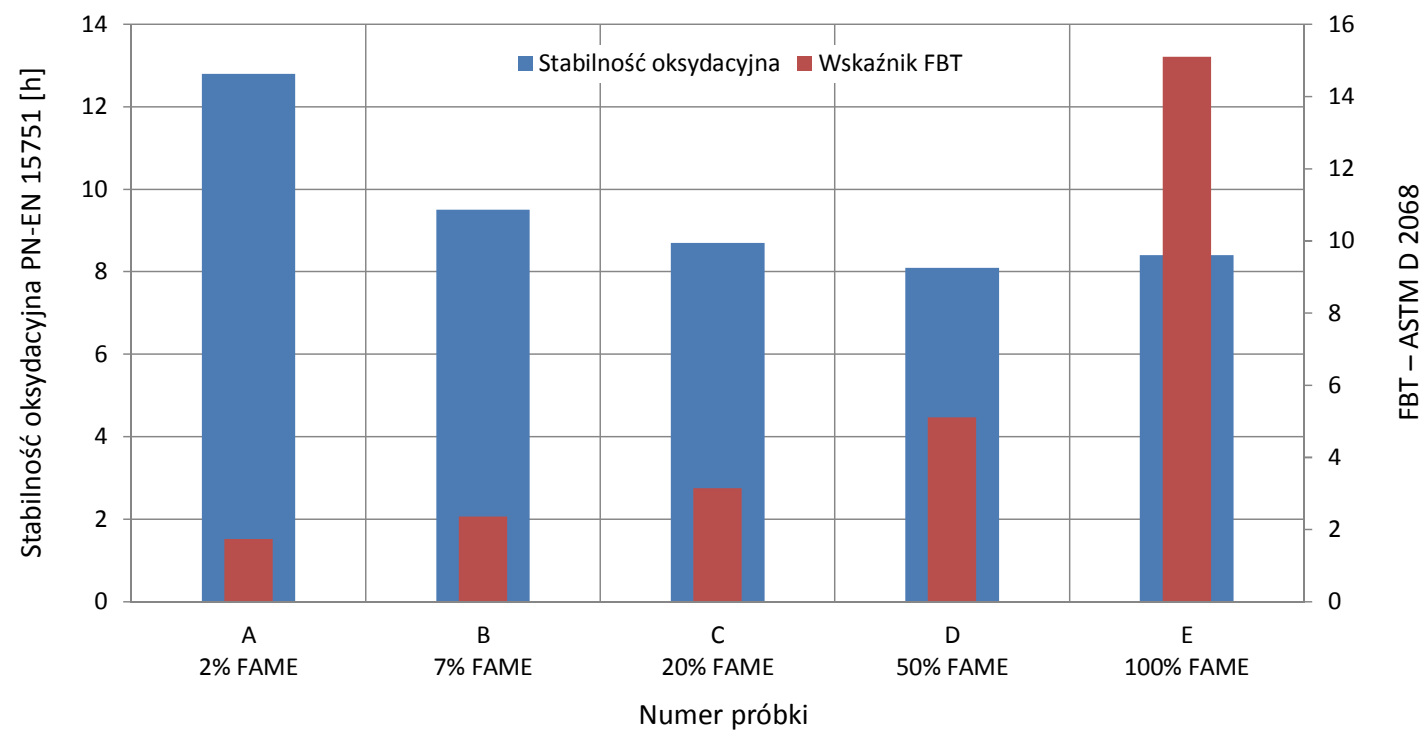

Rys. 7. Próbki zestawiane w INiG - PIB z oleju bazowego i FAME A (wartości początkowe)

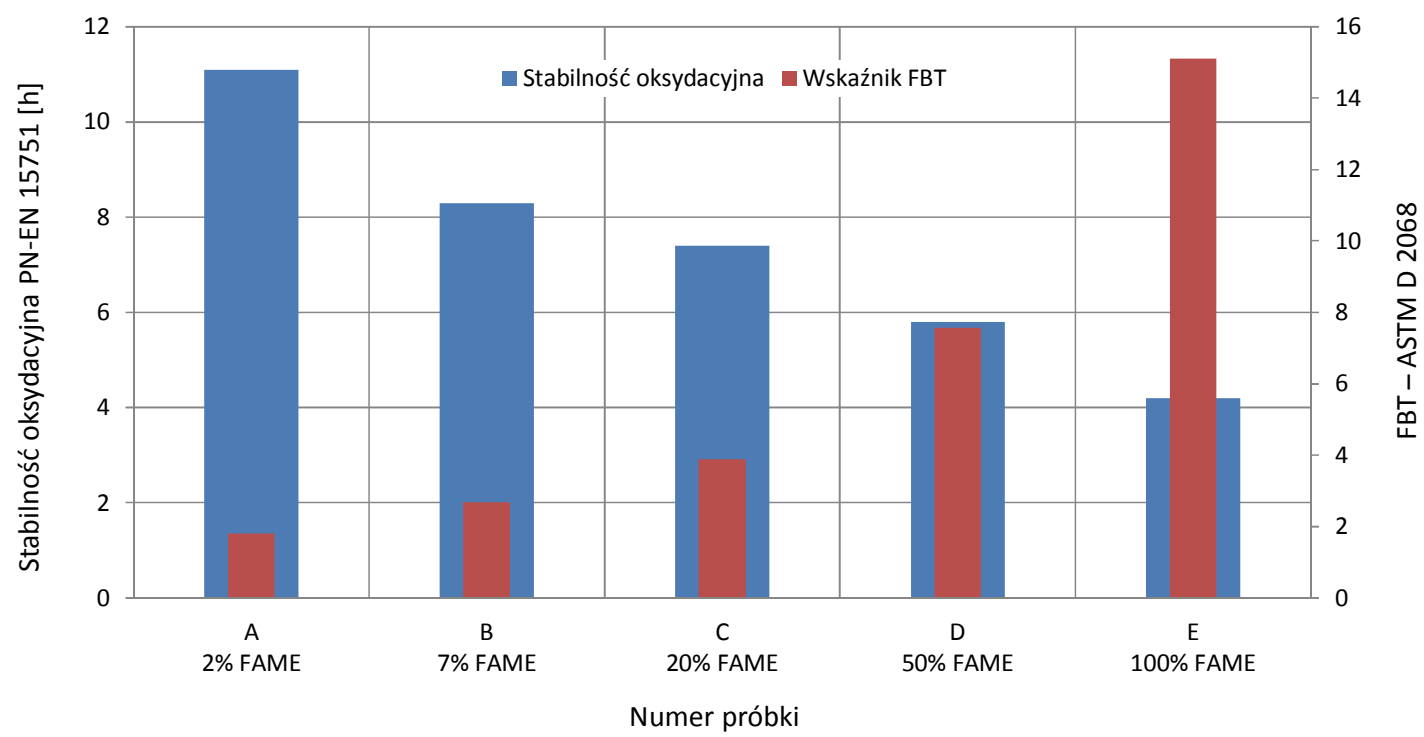

Rys. 8. Próbki zestawiane w INiG - PIB z oleju bazowego i FAME A (wyniki uzyskane po 1 miesiącu przechowywania w warunkach pokojowych) 
oksydacyjna powyżej 8 h), był bardzo różny - od wartości $\mathrm{FBT}=1,13$ do $\mathrm{FBT}=30,03$.

Można stwierdzić, że wskaźnik FBT paliwa zależy od jakości stosowanego do jego komponowania FAME. Paliwo zestawione z FAME o wyższym wskaźniku FBT również wykazywało większą skłonność do blokowania filtrów paliwowych.

Na podstawie badań - przeprowadzonych w warunkach laboratoryjnych na paliwach zestawianych w INiG - PIB - wykonanych na tych samych próbkach w miesięcznym odstępie czasowym można zauważyć zmniejszenie stabilności oksydacyjnej wyznaczonej metodą PN-EN 15751, przy równoczesnym wzroście wskaźnika FBT.

W przypadku próbek paliw zestawionych i badanych w warunkach laboratoryjnych zmniejszenie stabilności oksydacyjnej powoduje zwiększenie tendencji do blokowania filtrów paliwowych, o czym świadczy wzrastający wskaźnik FBT.

Prosimy cytować jako: Nafta-Gaz 2016, nr 6, s. 461-467, DOI: 10.18668/NG.2016.06.10

Artykuł nadesłano do Redakcji 11.01.2016 r. Zatwierdzono do druku 29.03.2016 r.

Artykuł powstał na podstawie pracy statutowej pt. Ocena korelacji odporności na utlenianie paliw do silników wysokoprężnych oraz skłonności do blokowania filtrów FBT - praca INiG - PIB na zlecenie MNiSW; nr zlecenia: TE/69/2015, nr archiwalny: DK-4100-69/15

\section{Literatura}

[1] Biernat K.: Wymagania i perspektywy rozwoju jakości olejów napędowych przeznaczonych do eksploatacji szczególnie $w$ warunkach komunikacji miejskiej z uwzględnieniem ochrony środowiska. Studia Ecologiae et Bioethicae 2004, nr 2, s. 431-449.

[2] Block J., Doyle J., Grossbauer S., Grove B., Johnson P., Klick P.: Fuel Filtration Reality Check Update. Clean Fuel \& Lubricant Solutions White Paper, February 2013.

[3] Luque R., Melero J. A.: Introduction to advanced biodiesel production. [W:] Luque R., Melero J. A. (eds.): Advances in Biodiesel Production. Processes and technologies. Woodhead Publishing Series in Energy 2012, vol. 39, s. 1-9.

[4] Markowski J.: Badanie stabilności nowych dodatków FBC oraz uszlachetnionych tymi dodatkami paliw. Nafta-Gaz 2011, nr 10, s. 736-741.

[5] Sacha D.: Nowe narzędzia badawcze do oceny właściwości użytkowych paliw do silników o zapłonie samoczynnym. Nafta-Gaz 2012, nr 2, s. 133-137.

[6] Wood J.: UK refiners introduce filter blocking test for diesel. www.forecourttrader.co.uk (dostęp: marzec 2014).

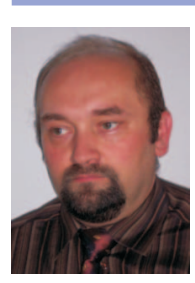

Mgr inż. Dariusz SACHA

Starszy specjalista badawczo-techniczny w Zakładzie Oceny Właściwości Eksploatacyjnych.

Instytut Nafty i Gazu - Państwowy Instytut Badawczy ul. Lubicz $25 \mathrm{~A}$

31-503 Kraków

E-mail: dariusz.sacha@inig.pl

\section{Akty prawne i normatywne}

[7] ASTM D 2068-14 Standard Test Method for Determining Filter Blocking Tendency.

[8] PN-EN 14214+A1:2014-04 Ciekte przetwory naftowe - Estry metylowe kwasów tluszczowych (FAME) do użytku w silnikach samochodowych o zapłonie samoczynnym (Diesla) i zastosowań grzewczych - Wymagania i metody badań.

[9] PN-EN 15751:2014-05 Paliwa do pojazdów samochodowych - Estry metylowe kwasów tluszczowych (FAME) jako samoistne paliwo $i$ ich mieszaniny z olejem napedowym - Oznaczanie stabilności oksydacyjnej metoda przyspieszonego utleniania.

[10] PN-EN 16091:2011 Ciekte przetwory naftowe-Paliwa i mieszaniny ze średnich destylatów naftowych i estrów metylowych kwasów tluszczowych (FAME) - Oznaczanie stabilności oksydacyjnej metoda szybkiego utleniania w małej skali.

[11] PN-EN 590:2013-12 Paliwa do pojazdów samochodowych - Oleje napędowe - Wymagania i metody badań.

[12] PN-ISO 12205:2011 Przetwory naftowe - Oznaczanie stabilności oksydacyjnej średnich destylatów paliwowych.

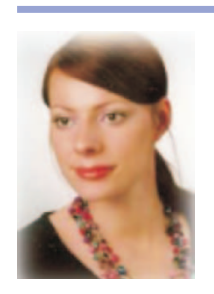

Mgr inż. Magdalena ŻÓŁTY

Specjalista badawczo-techniczny w Zakładzie Oceny Właściwości Eksploatacyjnych; kierownik Laboratorium Badań Właściwości Użytkowych.

Instytut Nafty i Gazu - Państwowy Instytut Badawczy

ul. Lubicz 25 A, 31-503 Kraków

E-mail:magdalena.zolty@inig.pl 